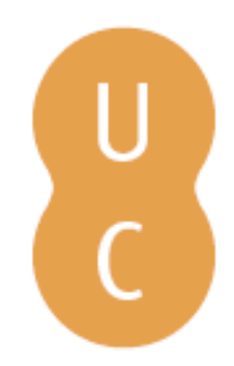

\title{
pompalina
}

\section{Radon in neotectonics and earthquake prediction}

Autor(es): $\quad$ Aumento, Fabrizio

Publicado por: Imprensa da Universidade de Coimbra; Laboratório de Radioactividade Natural da Universidade de Coimbra

URL

persistente: URI:http://hdl.handle.net/10316.2/36284

DOI: $\quad$ DOI:http://dx.doi.org/10.14195/978-989-26-1009-2_1

Accessed : $\quad$ 26-Apr-2023 09:27:41

A navegação consulta e descarregamento dos títulos inseridos nas Bibliotecas Digitais UC Digitalis, UC Pombalina e UC Impactum, pressupõem a aceitação plena e sem reservas dos Termos e Condições de Uso destas Bibliotecas Digitais, disponíveis em https://digitalis.uc.pt/pt-pt/termos.

Conforme exposto nos referidos Termos e Condições de Uso, o descarregamento de títulos de acesso restrito requer uma licença válida de autorização devendo o utilizador aceder ao(s) documento(s) a partir de um endereço de IP da instituição detentora da supramencionada licença.

Ao utilizador é apenas permitido o descarregamento para uso pessoal, pelo que o emprego do(s) título(s) descarregado(s) para outro fim, designadamente comercial, carece de autorização do respetivo autor ou editor da obra.

Na medida em que todas as obras da UC Digitalis se encontram protegidas pelo Código do Direito de Autor e Direitos Conexos e demais legislação aplicável, toda a cópia, parcial ou total, deste documento, nos casos em que é legalmente admitida, deverá conter ou fazer-se acompanhar por este aviso.

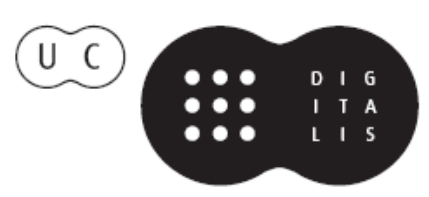




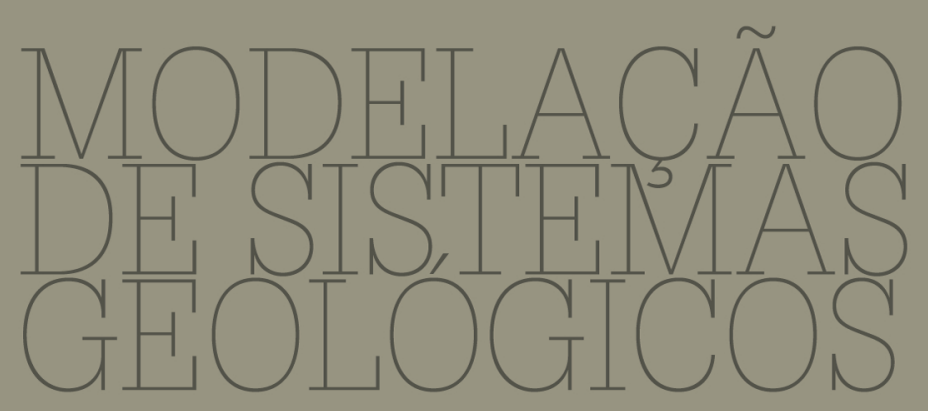

Homenagem ao Professor Doutor Manuel Maria Godinho

L.J.P.F. Neves, A.J.S.C. Pereira,

C.S.R. Gomes, L.C.G. Pereira,

A.O. TAVARES

IMPRENSA DA UNIVERSIDADE DE COIMBRA

CoImBra University Press 


\title{
MODELAÇÃO \\ DE SISTEMAS \\ GEOLÓGICOS
}

Homenagem ao Professor Manuel Maria Godinho

\section{Radon in neotectonics and earthquake prediction}

\author{
Fabrizio Aumento ${ }^{1}$ \\ ${ }^{1}$ Geoscientific Consultant, Montefiascone (VT), ITALY, fabaumento@tiscali.it
}

Key-words: Radon, Neotectonics, Mapping, Earthquakes.

\begin{abstract}
Researchers world-wide have spent the last 60 years in trying to develop reliable systems which might provide early warnings prior to the occurrence of earthquakes. Amongst the techniques most studied have been variations in Radon concentration, as measured both in the sub-soil and in ground water. In some cases major increases in Radon emissions, followed by rapid decreases, were reported prior to major earthquakes; these gave very successful predictions that earthquakes were forthcoming; the Haicheng (China) earthquake of 1984 is a fine example of successful predictions. On other occasions identical monitoring systems failed to provide reliable precursors; either false or even no alarms at all were given, as in the Tangshan (China) earthquake of 1985. Poor results continued in subsequent years. The L'Aquila earthquake of 2009 prompted us to report on results of Italian studies on Radon gas variations as applied to exploration, neotectonics and earthquake prediction. These studies are based on data stored from 1997 from two arrays of twelve simultaneously recording Radon stations, one on the volcanic island of Terceira, Azores, Portugal and the other on the Appenninic region of Northern Latium, Italy. We show that it is not sufficient to study data from isolated recordings of variations in Radon peak intensities. There is much more to be learned from multiple, long term data analyses; these permit us to define the characteristic Radon "signals" in each area studied. Unwanted interferences can then be removed from subsequent recordings. The residual anomalies may be indicative of neotectonic activity in both time and space.
\end{abstract}

\section{Introduction}

A massive $M=6.3$ earthquake struck the town of L'Aquila in the Abruzzi Region of Central Italy on $6^{\text {th }}$ April 2009, causing several hundred deaths. The event initiated a series of heated debates, amongst these, the dubious usefulness of Radon earthquake precursors was much discussed. Also under fire came the advice given by Civil Protection in advising citizen to return to the "safety" of their homes just hours before the main earthquake struck: 
authorities had completely disregarded the validity of anomalous Radon emissions as possible seismic precursors. Indeed, Radon alone may not be the answer to earthquake prediction; in the past it has given both encouraging and false results; events in China in the late 90s were good examples of unreliable precursors. But there is abundant evidence from other past events to suggest that there may be some link between Radon, active faults and telluric movements, sufficient to make it worthwhile to at least take into consideration anomalous Radon emissions, especially when combined with other possible precursors. Anomalous Radon signals had been recorded at L'Aquila by Gianpaolo Giuliani from the Gran Sasso laboratories, but these were not taken into consideration by Civil Protection. Indeed, Giuliani was publicly derided by authorities, even to the point of being accused of false alarmism. Senior Civil Protection staff were subsequently charged with manslaughter for having completely disregarded Giuliani's evidence and incorrectly advising the population of L'Aquila on that fateful night of $6^{\text {th }}$ April.

So, if Radon variations may at times be effective in the study of earthquakes, to the extent that increases in levels of ${ }^{222} \mathrm{Rn}$ were recognised by IASPEI (IUGG Meeting, Perugia, 2007) as being possible earthquake precursors, what stops the gas from giving a consistent, reliable early warning signal? The situation is complicated by the very nature of $\mathrm{Rn}$ : a radioactive, noble gas, with a very short half life, unable to combine with other elements, but at the same time responsive to other natural disturbances. When one measures the quantity of Radon gas being emitted from below ground, one is in fact detecting the sum of a whole series of factors affecting that emission before the gas reaches recording instruments. This is true both for analyses integrated over time by passive SSNTD detectors and for continuous real-time analyses as determined by electronic instrumentation. Amongst those factors that play an important part in affecting the gas flow, each of which must be accounted for, we find:

- The surrounding geology, its Radon-generating capability, and its permeability (high for pyroclastics and low for clays, the latter having effective sealant properties).

- Cyclic luni-solar effects (Radon "tides" produced by the gravitational effects of the Moon and Sun), giving rise to two peak emissions every 24 hours (synchronous with marine and Earth tides). See Kiess et al. 1999; Aumento 2002.

- Content and microstructural location of Radon's generator (Radium); Radium residing deep within crystal lattices will generate Radon which will remain trapped there and never reach the surface. 
- The tectonic stability of the area; small seismic shocks, even the transit of heavy vehicles will dilate or tighten existing conduits (fractures, hairline cracks, continuous porosity), which facilitate the migration of Radon.

- The proximity to superficial aquifers; underground water flows tend to pick up Radon in solution and transport it to sites of lower concentrations.

- Similarly, air currents along faults and fractures will pick up and transport Radon.

- The ambient humidity, rainfall, atmospheric pressure, winds, and temperature.

- And finally, the telluric signals we are hoping to detect.

A single measurement of the Radon outflow at a particular site will have been subjected to all these disturbances; this makes it difficult to pick out the influence of a specific effect, including that due to tectonic activity.

\section{Tectonic mapping}

Time-integrated spot measurements, using nuclear track films (SSNTDs such as LR-115, CN-85 and others), screened against humidity and buried to standard depths for periods of up to one month have been used as survey tools since the early '70s. At first they were used to detect buried Radonemitting ore bodies (U and Th deposits in particular). Subsequently in the ' $80 \mathrm{~s}$ it was found that Radon mapping could be used to distinguish between open/active faults/fractures from those which were sealed and inactive, even when the latter still retained good morphological features.

In Northern Latium, from Lake Bolsena (a collapsed caldera) through Viterbo (extinct Cimini volcanoes) to Lake Bracciano (extinct Sabatini volcanoes to the South), nuclear track measurements below ground began in 1983. These were commissioned by an AGIP-ENEL Joint Venture intent in finding geothermal activity, the fluids of which were thought to transport Radon gas from thermal sources at depth to surface emissions. The project was extended by the Italian National Research Council in its study of deeply buried, open fractures, again as possible conduits for deep geothermal fluids. After some 3,000 measurements, spread over several years, covering the area (from 1 to 15 measurements per square kilometre), very few Radon emissions were detected either along those faults of regional geological significance (Appenninic trending faults, NW-SE) or those due to the Bolsena caldera collapse. Both these systems appeared to be sealed and inactive; but Radon emanations showed that they had been replaced by new 
systems of faults: active and open anti-Appenninic faults, trending NE-SW; examples include the Celleno and Bagnoregio faults: see map of Figure 1 (Aumento \& Cherubini, 2008).

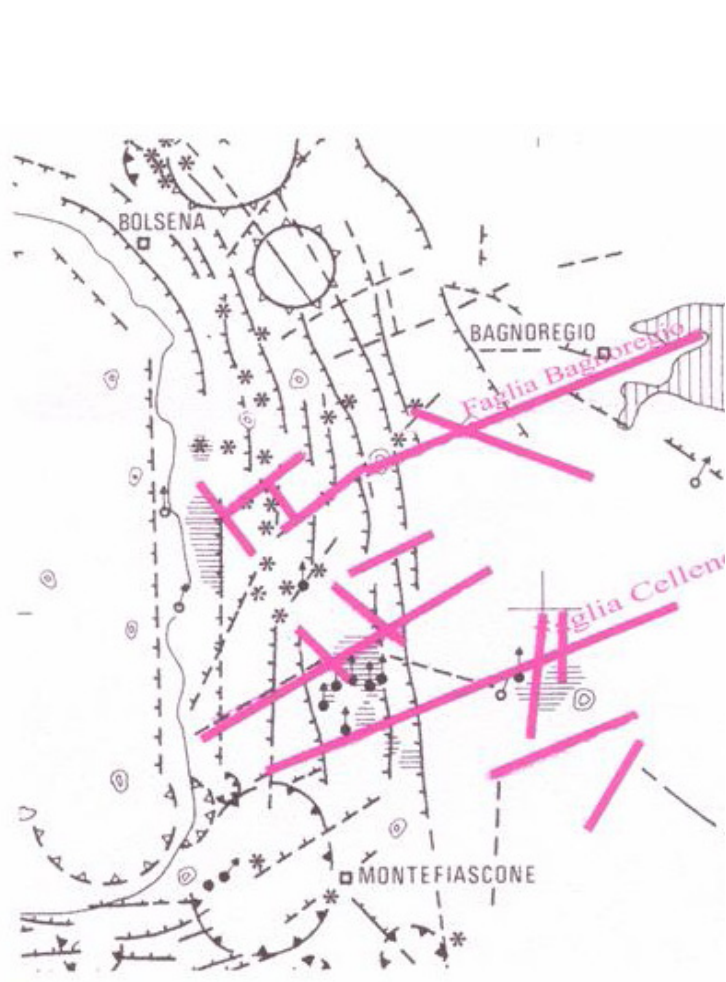

The latter system is particularly interesting because, although topographically featureless, the Bagnoregio fault trends from Lake Bolsena (E-NE), past the extreme eastern end of the town of Civita di Bagnoregio and on to the seismically unstable Umbria Region to the East. Radon emissions along this fault line are commonly above $8,000 \mathrm{~Bq} / \mathrm{m}^{3}$, and have reached $40,000 \mathrm{~Bq} / \mathrm{m}^{3}$ in places.

Figure 1. Lake Bolsena, Upper Latium, tectonic map.

(The thick dark lines are active faults/ fractures which are currently leaking Radon. Inactive faults and other tectonic lineaments are represented by thin lines.)

This fault has often moved in the recent past; the last major movements occurred in the 1670's, when tuffs making up an upper section of the town collapsed into the valley below.

Similar survey techniques were later used in geothermal exploration campaigns in Mexico in 1979-1980 (Gutierrez Negrin \& Aumento 1982), in Zambia (Lake Tanganyika) in 1985-1987, on the island of Terceira in 19921994 (Aumento 1994), and then over the Mojave desert, in California and Nevada (1992-2000), again for geothermal exploration purposes. The "anomaly" maps so generated provided useful indications as to where to continue exploration, and where geothermal activity was no longer active (Figure 2). 


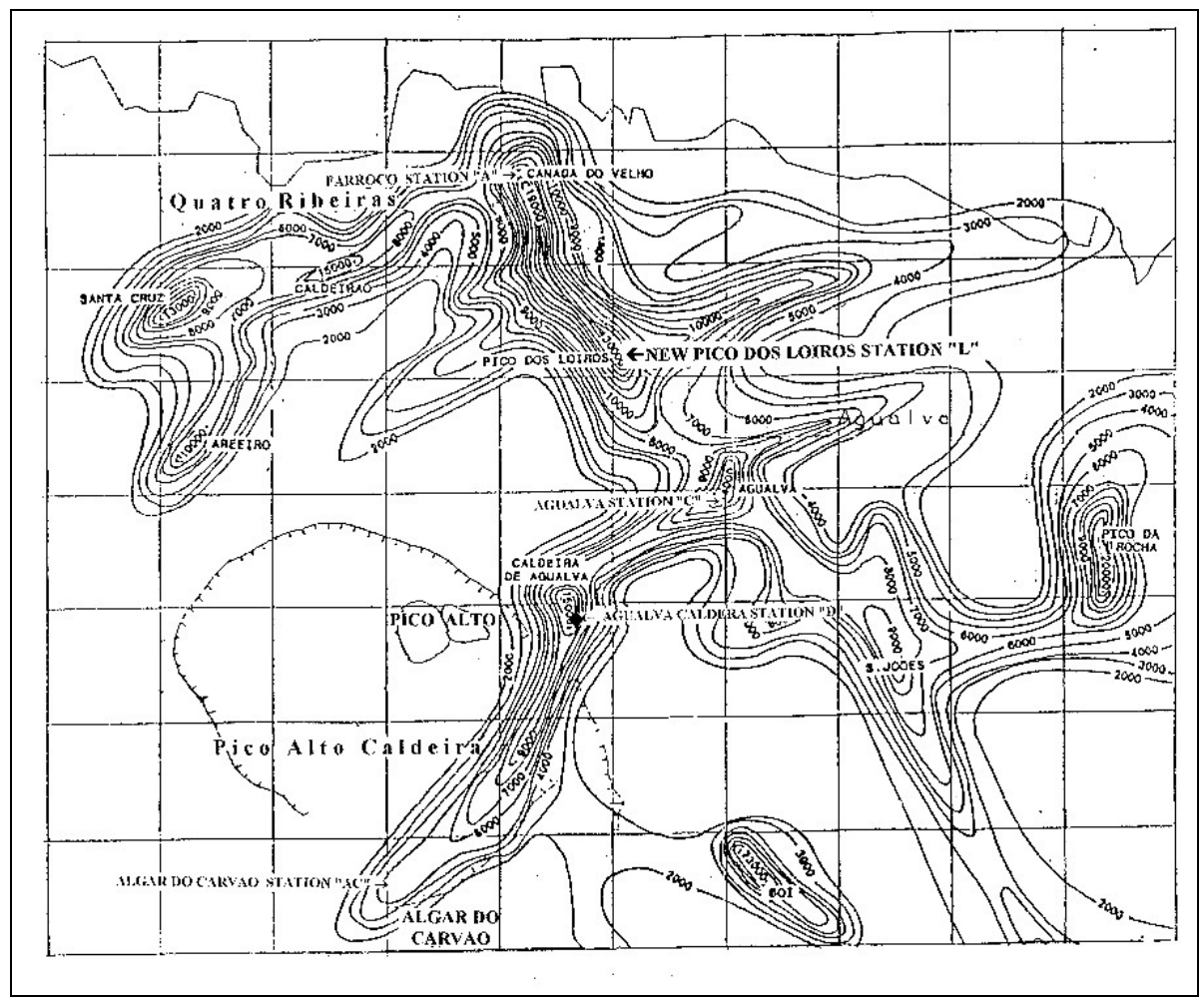

Figure 2. Ground Radon concentrations measured around Pico Alto, Terceira. The map was generated by contouring over 1000 integrative SSNTD stations.

\section{Earthquake monitoring and prediction}

Based on long-term studies world-wide since the early 1960's, some earthquake precursors had been tentatively identified (e.g., changes in ion concentrations in water, variation in $\mathrm{He}, \mathrm{Ne}, \mathrm{Ar}, \mathrm{Rn}$ and $\mathrm{N}_{2}$ in the environment, the abnormal behaviour of some animals, series of milder foreshocks before major earthquakes, sudden water-level change in wells, ground deformation, stress build-up in the country rocks (which may in turn alter electric and electromagnetic properties of rocks). The problem with these precursors is that they do not behave consistently: in China, for example, a 1975 early warning and evacuation based on Radon and other parameters saved 150,000 lives when a $M=7.3$ earthquake struck the Haicheng area (Fu \& Tatsuoka, 1984); similar detection techniques did not save some 655,000 souls killed in Tangshan, China, later that year when a 7.8 quake struck unexpectedly; this was reportedly the second largest earthquake ever recorded to have affected human lives: no precursors had 
been detected on that occasion (Geotimes, 2005). More effective was the 1995 Kobe (Japan) warning provided by groundwater Radon in wells: concentrations in water started gradually increasing several years before the earthquake, from an original $20 \mathrm{~Bq} / 1$, to $60 \mathrm{~Bq} / 1$, to a maximum of $250 \mathrm{~Bq} / 1$ just before the earthquake struck and Rn concentrations dropped back to 30 $\mathrm{Bq} / \mathrm{l}$ (Igarashi, 1995). It seems that these early warnings are subject to so many different influences that, when taken individually, they behave erratically; they have therefore been discarded and considered unreliable by many researchers. This makes earthquake prediction a controversial issue.

Nevertheless, as shown above for catastrophic events, major changes in Radon concentration have been observed in several earthquake-prone zones a few months/days/hours before, during and after large earthquakes (Martinelli, 1999, Papastefanou et al., 1999, Coutinho et al., 2001, amongst several others). Such behaviour was observed in deep mines, cellars and wells where Radon concentration fluctuations due to disturbing environmental factors could virtually be ruled out. Therefore, it is tempting to consider a sudden erratic fluctuation in Radon concentration, particularly in deep wells in an earthquake-prone zone, as a potential omen for an earthquake (see for example Zhang Zhaocheng and Zhang Wei, 1999). Again, this relationship is not valid consistently.

Because of the short half-lives of $\mathrm{Rn}$ isotopes, it is generally and incorrectly believed that most of the naturally occurring $\mathrm{Rn}$ in the environment is made up of the longer-lived ${ }^{222} \mathrm{Rn}$ isotope (3.8 days half life) generated only a few tens of metres in depth in the Earth's crust. In effect, fluid transport and open fractures/conduits can very efficiently carry both ${ }^{222} \mathrm{Rn}$ and the shorter-lived ${ }^{220} \mathrm{Rn}$ isotope (Thoron, 52 seconds half-life) from greater depths and over greater distances during their life times (Fleischer and Mogro-Campero, 1978), especially when, in some volcanic rocks, Thoron sometimes occurs as the predominant isotope. We have seen these effects in action over geothermal fields, where fluids transport Radon both vertically and laterally over several tens of kilometres.

A standard argument for explaining the variation in Radon concentration in faults and water wells before, during and after an earthquake is the variation in release of the gases entrapped in crustal rocks due to pore collapse and/or opening of micro-fractures caused by stress variations (Hushinuma et al., 1999; Tuccimei et al., 2010). Being an inert gas, variations in Radon concentration cannot be due to chemical reactions with other substances exposed by crack build-up in the rocks.

One major problem in using Radon as an earthquake precursor is in the inability to identify the origin of Radon pulses recorded. Major Rn peaks 
are not necessarily due to telluric activity. We have recorded numerous strong peaks without associated seismicity, at Vetralla (nr Viterbo, Northern Latium), for example (Figure 3).

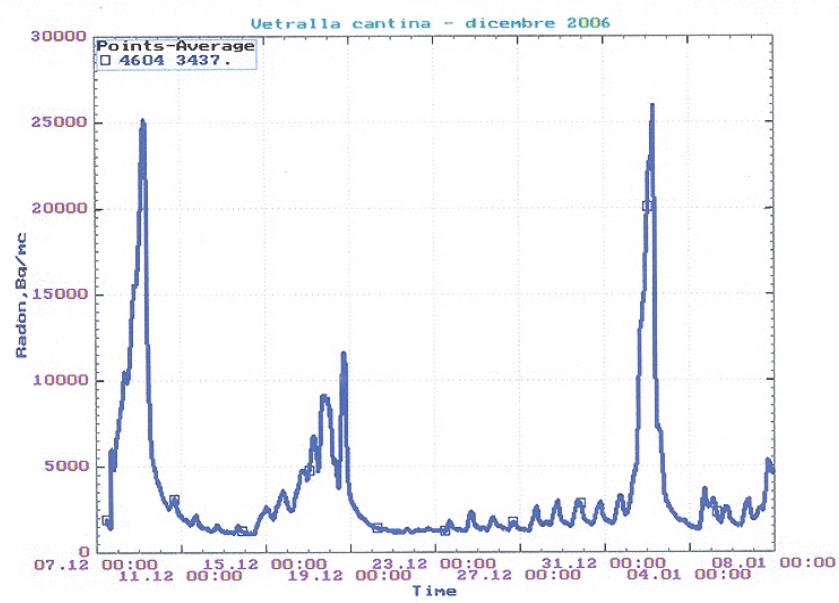

Figure 3. Radon emission concentrations measured continuously during the month of December 2006 in a deep cave at Vetralla, Upper Latium. (The large peaks registered had no associated seismic signals. The small peaks in between are the standard, daily luni-solar controlled Radon emissions.)

It is therefore of primary importance to be able to sort out and identify tectonically induced Radon peaks from other possible causes.

We have used results from two Radon networks, each consisting of up to twelve multiple, synchronous underground monitoring stations (in Terceira, Azores, Portugal and in Upper Latium, Italy: Aumento et al. 2002; Aumento and Cherubini, 2008; Aumento, Cristaldi and Zucchetti, 2009).The distribution, timing, size and structure of the Radon pulses recorded by the networks were analysed in detail and shown only in some cases to be related to telluric modifications of the otherwise systematic lunisolar tidal control; the latter is one of the main controlling factors in Radon emissions, both as far as pulse time and strength are concerned (Figure 4). 


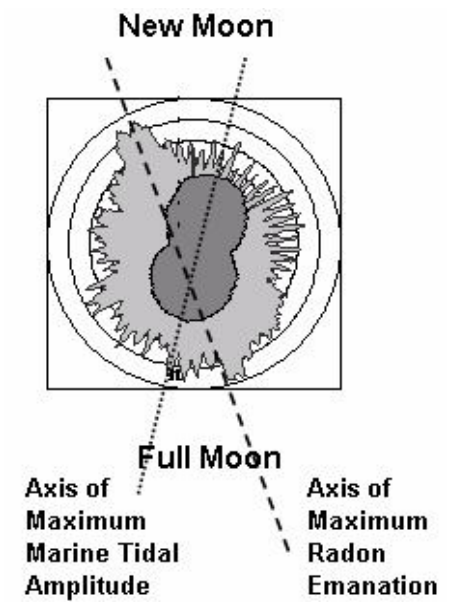

Figure 4. Radon emissions at Pico Alto integrated monthly during one calendar year showing the relationship between Radon maxima, marine tides and phases of the Moon.

Before selecting a site for the installation of continuous monitoring equipment, data from ground-Radon surveys were used in Latium (Figure 1) and Terceira (Figure 2) to chose the locations of active faults which might possibly permit Radon fluxes to reach the surface unhindered. For the Radon data to be useful, several monitoring sites must be operational in each region so as to produce a well-spaced array capable of indicating the timing, provenance and subsequent direction of Radon pulses. Each site must be subject to a minimum of disturbances from external influences, as discussed above. Deep, locked cellars or natural caves usually made the best sites. Since one factor controlling Radon emissions is that of luni-solar gravitational effects, Radon emission intensities recorded on a 60 second basis by the instrumentation were subsequently re-plotted as a function of lunar days/months and not calendar months. When there were no major external secondary disturbances, emission intensities, plotted month after lunar month, showed coincident peaks twice a day, morning and evening directly related to sunrise and sunset times. A typical systematic graph was then generated integrating several lunar months at a time, from which very clear repetitive, monthly patterns emerged (Figure 5). 


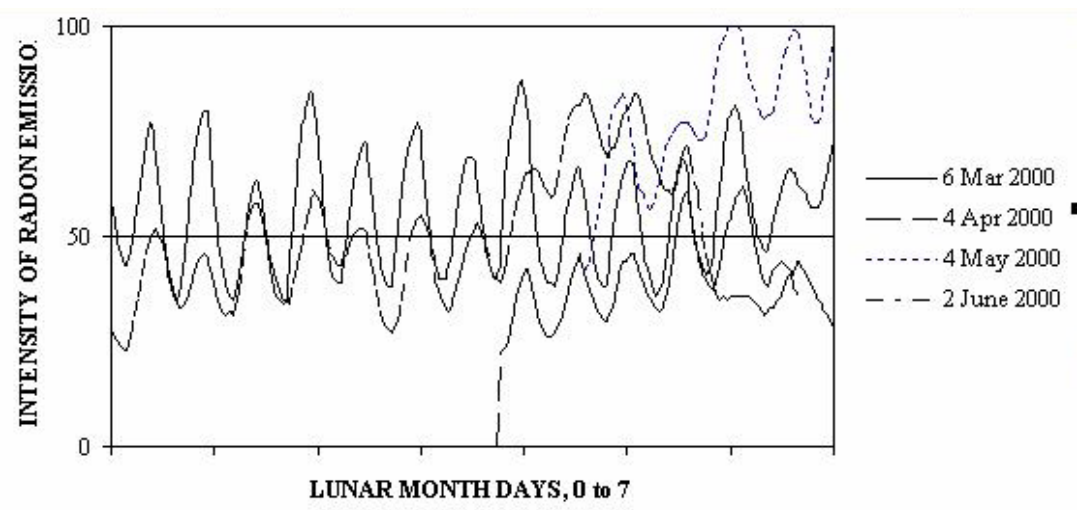

Figure 5. Radon emissions for the first six lunar days of each month showing their repetitive, synchronous pattern when undisturbed by tectonic or other influences.

If a major seismic event occurred during a particular recording period, the new trace no longer coincided with those of previous months; the event will be visible as a sudden, strong disturbance, in terms of both time and intensity, and, given the availability of multiply deployed stations, will be seen to come and leave from a particular direction. Such events have been recorded on Terceira (Figure 6) and at Civita di Bagnoregio: these stations, placed deep in caves, where there are few outside disturbances, have shown the arrival of sudden Radon surges, with emissions ranging from background values of 3,000 to $4,000 \mathrm{~Bq} / \mathrm{m}^{3}$ to over $35,000 \mathrm{~Bq} / \mathrm{m}^{3}$ in a matter of minutes. Simultaneous, detailed recording of all meteorological data by local authorities showed that these surges were in no way related to atmospheric influences.

In the Upper Latium region of Italy, continuous monitoring commenced on $10^{\text {th }}$ October 1997 soon after the Assisi earthquake struck (on $26^{\text {th }}$ September 1997). Recordings were interrupted only by instrumental damage due to excessively humid conditions. Major Radon flux variations were detected by our arrays from remarkably distant sources: in coincidence with the aftershocks of the 1997 Assisi earthquake $\left(10^{\text {th }}\right.$ October to $6^{\text {th }}$ December 1997), some $80 \mathrm{~km}$ away, and recently (2009) from the more distant one at L'Aquila, $120 \mathrm{~km}$ away. In the case of these major earthquakes, large, broad Radon peaks developed at each of the component stations, with maxima exceeding $35,000 \mathrm{~Bq} / \mathrm{m}^{3}$; peaks then lost intensities within a few days (Figure 7). However, on several other occasions Radon emissions recorded in Latium peaked repeatedly beyond $20,000 \mathrm{~Bq} / \mathrm{m}^{3}$ (Figure 8), without accompanying telluric events. These may possibly have been due to some very local events which had passed undetected. 


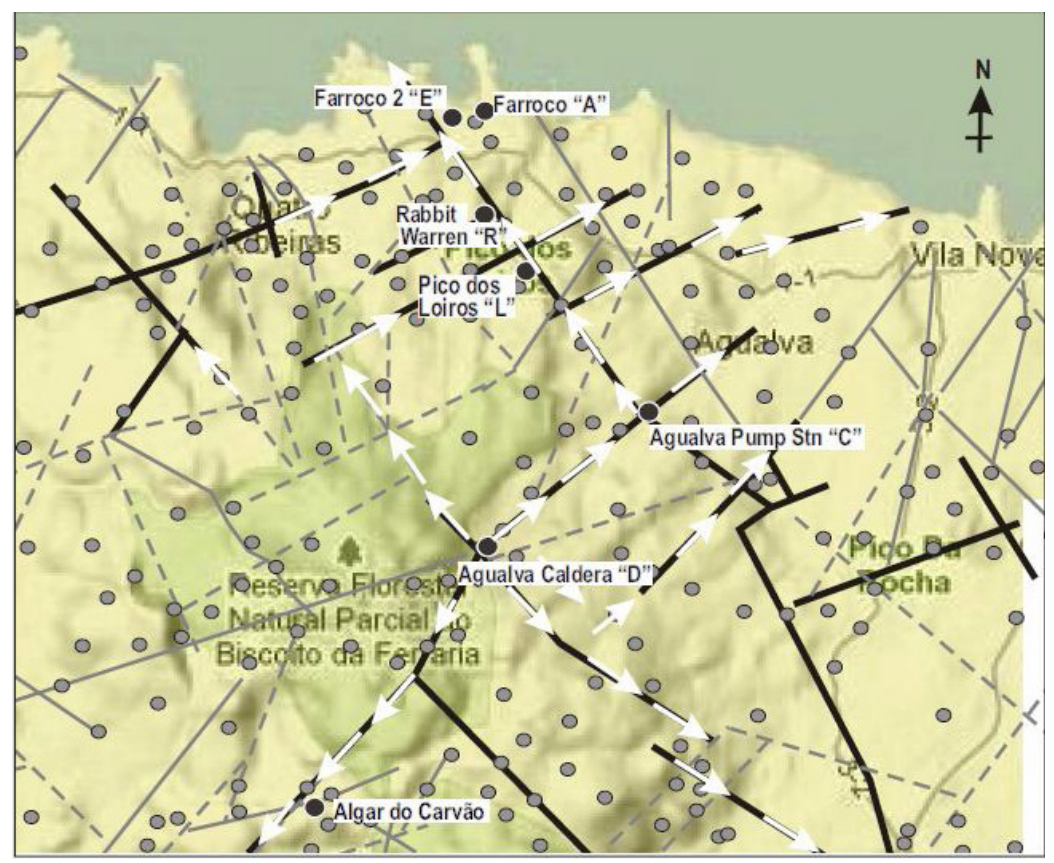

Figure 6. Tectonic map of the NE slopes of Pico Alto Volcano, showing active faults and Radon flow patterns along these lineaments from their origin to sea level. Small grey dots are Rn stations.

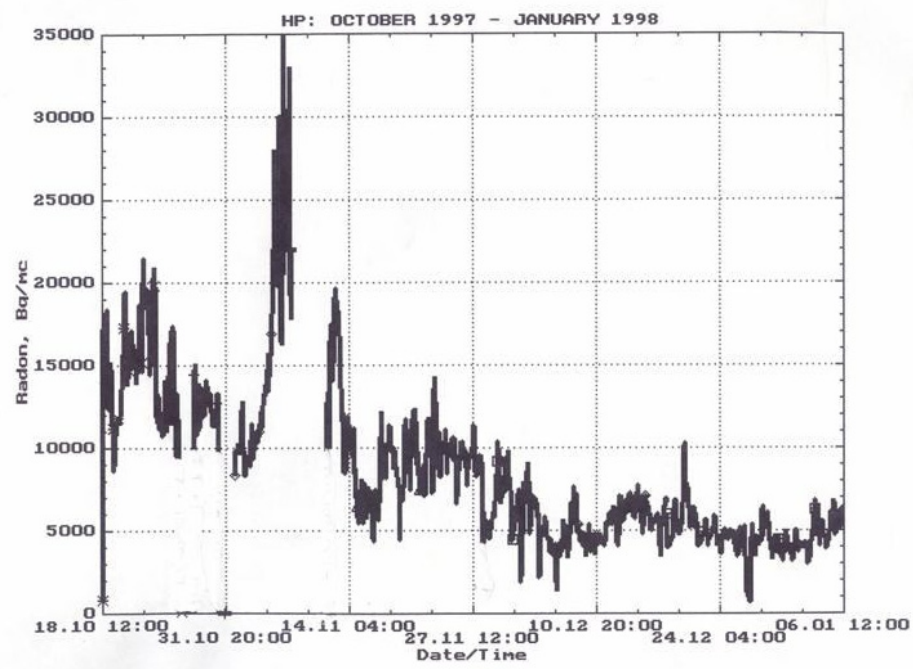

Figure 7. Strong Radon signals (off scale) recorded in a deep cellar at Bagnoregio coincident with after-shocks of the Assisi

(Umbria) earthquake, some $80 \mathrm{~km}$ away. (Oct. 1997-Jan. 1998). 


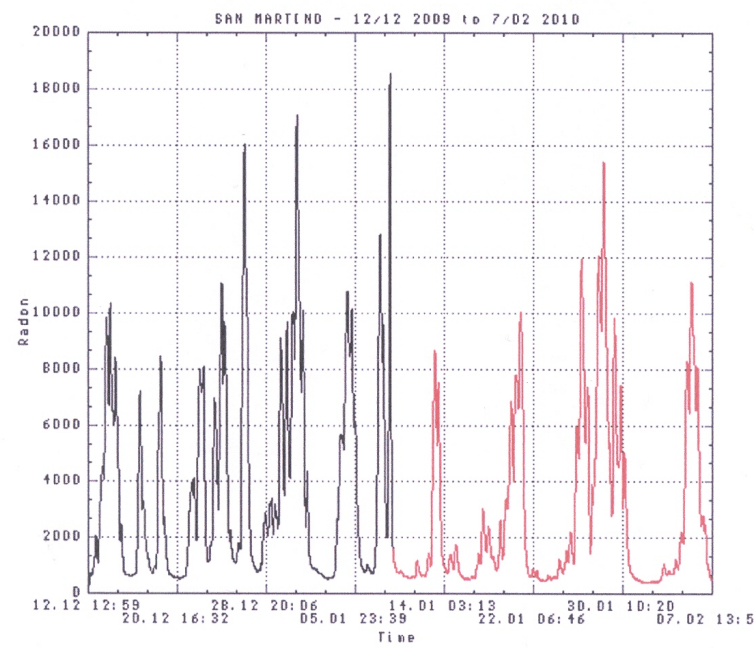

Figure 8. Radon emanations recorded in a deep cellar at San Martino nel Cimino, near Viterbo, Upper Latium. The vicinity to the Cimini hills (extinct volcanoes) aside, no direct relationship was found between these Radon pulses, tectonics or marine tides. (12 ${ }^{\text {th }}$ Dec. 2009-7 ${ }^{\text {th }}$ Feb. 2010).

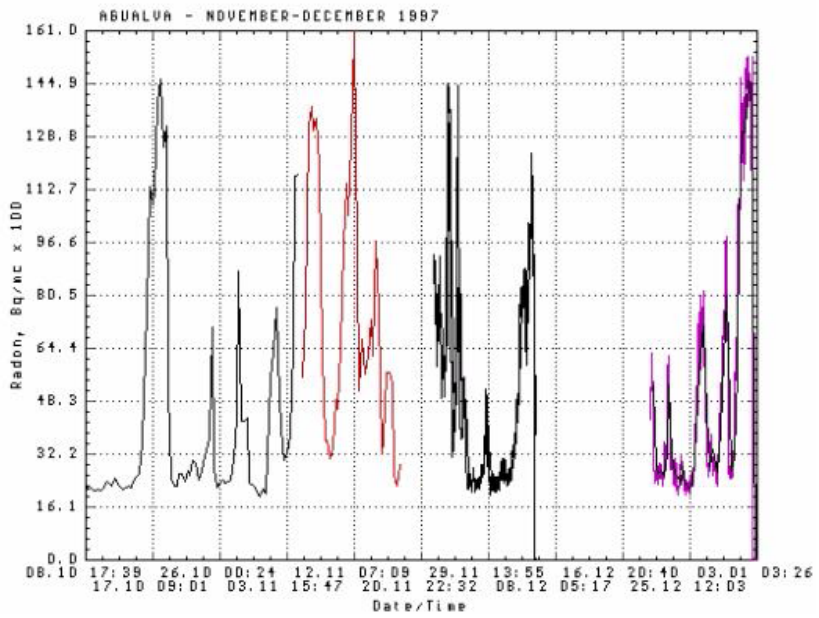

Figure 9. Radon emanations from near the summit of Pico Alto, at Agualva caldera. (Nov. - Dec. 1997)

On Terceira, although there were several instances of coincidences between local, anomalous Radon emissions and a large number of $\mathrm{M}<2$ earthquakes, statistical correlations between these small events and Radon did not produce a convincing story. On the contrary, when more significant events occurred, Radon stations could be seen to respond either to the stress system of the regional Azores/Gibraltar tectonic regime (NW-SE) or to the 
more local NE-SW Pico Alto volcanic regime (Figure 6). Peak intensities were seen to shift from one system to another as different tectonic regimes came into play. For example, immediately after a major earthquake on the adjacent island of Faial in July 1998, caused by movement on the regional NW-SE system, Radon intensities measured over said system were observed to drop steadily for several weeks. Subsequently, as underwater eruptions from the nearshore Serreta volcano picked up in intensity, with activity associated with the younger NE-W system, Radon stations over these lineaments showed marked increases in emissions.

Radon emanating from the geothermal field beneath the eastern flanks of Pico Alto volcano flows along open vertical faults/fractures, reaching the surface and then flowing down slope to the sea (Figure 6). Each day, the characteristic twin Radon peaks are first detected at the station nearest the source, i.e., at Agualva Caldera (550 m elevation); these peaks are very sharp and intense, and occur close to sunrise/sunset times (Figure 9), unaffected by marine tide times. Subsequently, as Radon migrates along interconnecting open fractures/faults, the Radon pulses are recorded sequentially, with ever increasing delay, at the down-slope stations: at Agualva Pump Station, then Pico dos Loiros and Rabbit Warren Stations. By this time peaks are not quite as intense, or as sharp, because Radon has travelled further, following a more complex set of fractures. Finally, the last appearances of the Radon pulses appear at sea level over faults at the two Farroco stations (Figure 6). By carefully synchronising the recordings at these different stations, one can follow the movements of Radon as it flows along faults/fractures down to the sea, picking up time delay and gradually losing intensity as it travels away from the source.

Furthermore, tectonics can open/close different conduits, modifying travel paths; travel pattern may become more complicated, and more variable. Indeed, Radon emanation graphs recorded at Farroco (Figure 10) were shown to be very variable, more complex, different from month to month. Not only did the shapes of the peaks vary, but peak times changed as travel paths became longer or shorter (Figure 11). In addition, sometimes more than the two peaks a day (am and pm) were recorded: a small percentage of the Radon may have found other conduits along which to travel, giving another set of smaller, systematic peaks, indicative of the arrival of a smaller fraction of the gas.

A particularly striking example of these time/path shifts was detected at the Farroco station during three years of study: Radon was twice delayed by several hours along its flow from source to sea (Figure 11), at first gradually between July 1997 and April 1998, and again from May 1998 to 
May 1999, and then very rapidly to June 1999 . These time shifts were seen to be quite independent of marine tide times, the Radon emissions not following the daily tidal delay progressions. Similar shifts were detected at Farroco and at other sea level stations on several other occasions.

For lack of data transmission capabilities in real time, all foregoing observations were performed in retrospect, in the laboratory, working on previously recorded data. The system works well for Radon mapping, but it is not suitable as an earthquake precursor in the short term. A central control station needs to be set up for each network to receive signals from all stations; data would be evaluated there in real time by experienced staff, who would issue early warnings as necessary. In the volcanic regions studied above, this is not quite so easy to accomplish: stations are often lacking electric power supplies, and are deeply buried in tuffs and lava flows, lithologies which shield all radio transmissions.
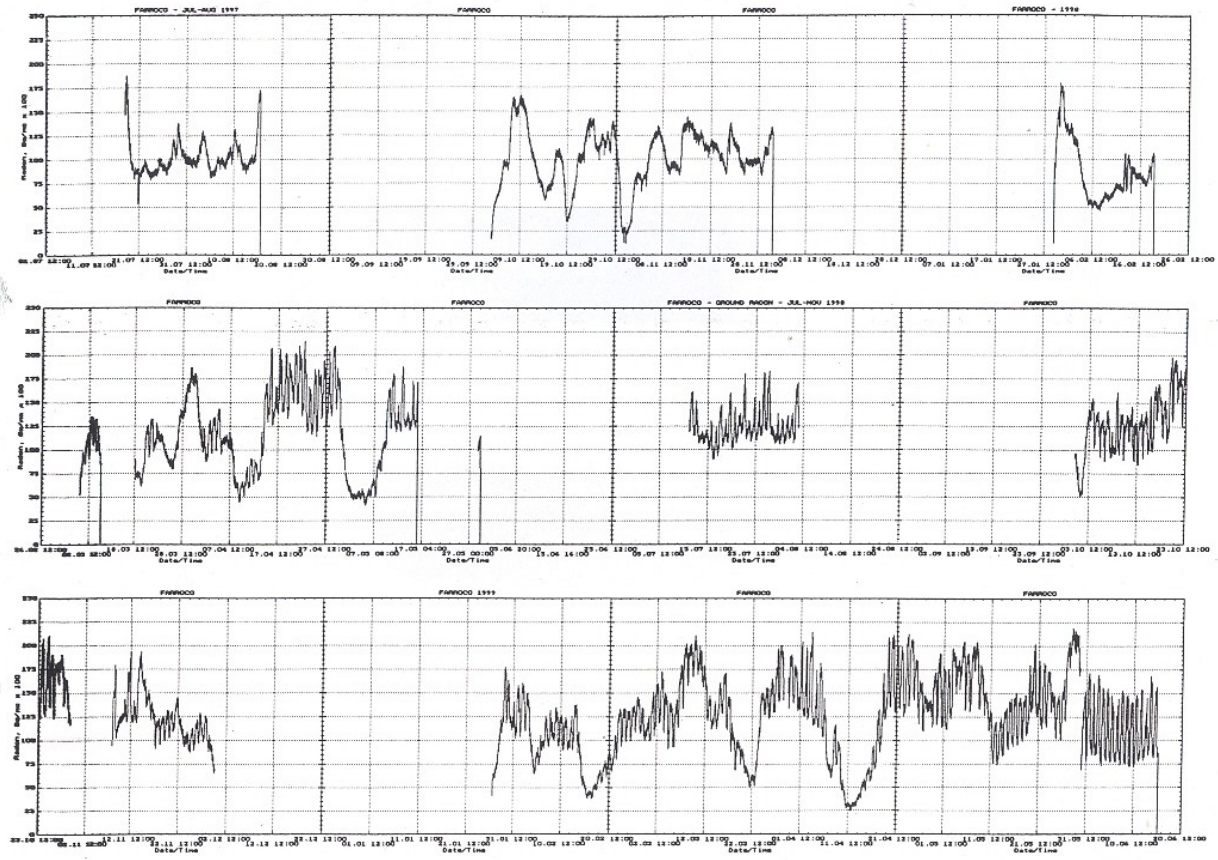

Figure 10. Radon emissions recorded at the Farroco Station from July 1997 to June 1998 showing the variable patterns at that site. 


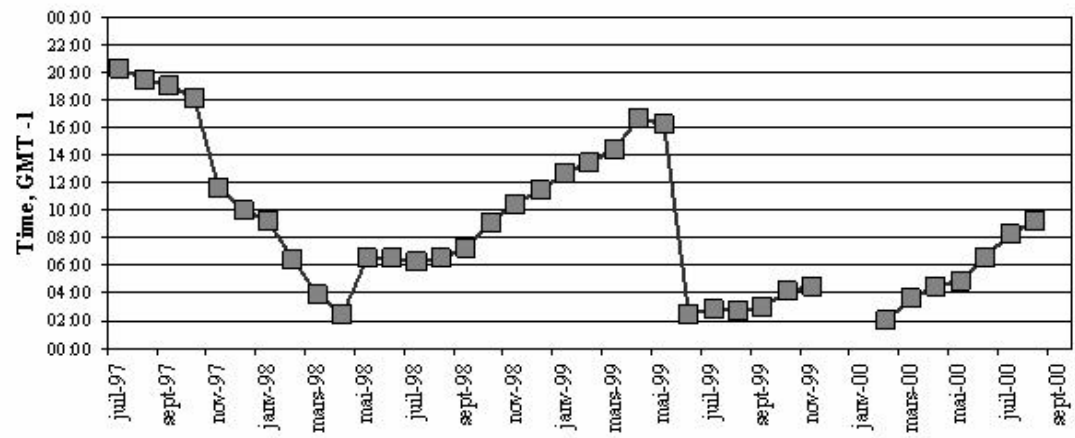

Figure 11. Radon emission times recorded at Farroco over a three year period for its main peak, showing both gradual and sudden time shifts due to the opening/closing of the faults/fractures available to the gas for its migration down to the sea. (July 1997-September 2000).

\section{Acknowledgements}

Over the last twenty or so years the Radon research summarized here was supported by a large number of agencies and colleagues; amongst them the Italian National Research Council, the European Community, Dr Frank Monastero of the Geothermal Program of the U.S. Air Force, Ormat Turbines (Nevada), AWARE Electronics Corp., the Republics of Portugal (the Azores), Mexico, Zambia, Kenya, Guatemala, El Salvador, the Dominican Republic, and Yemen. More recently, colleagues from Portugal (Drs Luis Neves, Rui Coutinho, and Alcides Pereira) loaned much needed instrumentation to replace equipment damaged by inclement weather.

\section{References}

Aumento F., (1989) - The Radon hazards in the central Italian volcanic province. Italian edition of Scientific American; July 1989, 9-10.

- (1994) - Terceira Geothermal, JOU2-CT92-0114. Final Report. 200 p.

- (2002) - Radon tides on an active volcano/tectonic/geothermal island (Pico Alto volcano, Terceira, Azores). $6^{\text {th }}$ International Conference on rare gas Geochemistry, Cuernavaca, Mexico, September 2001, Geofísica Internacional; 41/4, 499-505.

Aumento F. and Cherubini G. (2008) - Continuous radon monitoring of concealed active faults affecting Civita di Bagnoregio: tectonic and health hazards. International Tuff Towns Symposium, World Monument Fund, Civita di Bagnoregio, 14-17 May 2008.

Aumento F., Cristaldi M. and Zucchetti M. (2009) - Radon flux variations as earthquake precursors. MESAEP International Symposium, Bari, 7-11 October 2009.

Aumento F., Monastero F. C. (1999) - Variations in continuously monitored radon emanations on Terceira (Azores) reflect changes in tectonic stresses and volcanic activity, Supplement to EOS, Transactions; AGU 80/46, F982.

Aumento F., Monastero F. C., Dysle W. and Kendrick M. G. (1998) - Continuous radon monitoring of an active volcano-tectonic geothermal system, Terceira Island, Azores. Supplement to EOS, Transactions; AGU 79/45, F958. 
Aumento F. and Siciliani P.D. M. (2003) - Rilevamenti radon e previsioni sismotettoniche nella galleria idaulica di Eggi, Spoleto, Galileo 160, 30-32.Z

Coutinho R., Gaspar J., Aumento F., Pacheco J., Queiroz G. and Valadão P. (2001) - Emissões de Radão atravès dos solos registradas na ilha do Faial (Açores) após o terramoto de 1998. [Soil radon emissions recorded at Faial Island (Azores) following the 1998 earthquake]. 2 ${ }^{\circ}$ Simpósio de Meteorologia e Geofísica da APMG, Evora (Portugal), 12-13 February 2001

Fleischer R.L. and Mogro-Campero A. (1978) - Mapping of Integrated Radon Emanations for Detection of Long-Distance Migration of Gases Within the Earth: Techniques and Principles. J. Geophys. Res.; 83, 3539-3549.

Fu S. and Tatsuoka F., 1984. Soil liquefaction during Haicheng and Tangshan earthquakes in China: a review. Soils and Foundations; 24,/4, 11-29.

GEOTIMES (2005) - Earthquakes: "predicting the unpredictable". March 2005.

Gutierrez Negrin A., and Aumento F. (1982) - The Los Azufres, Michoacan, Mexico, geothermal field. J. Hydrology; 56, 137-162.

Hishinuma T., Nishikawa T., Shimoyama T., Miyajima M., Tamagawa Y. and Okabe S. (1999) Emission of radon and thoron due to the fracture of rock. Il Nuovo Cimento; 22 C/3-4, 523527.

Igarashi , G. (1995) - Ground water Radon anomaly before the Kobe earthquake. Science, 269, 60-61.

Kies A., Majerus J. and d'Oreye de Lantremange N. (1999) - Underground radon gas concentrations related to earth tides. Il Nuovo Cimento; 22 C/3-4, 287-293.

Martinelli G. (1999) - History of earthquake prediction researches. Il Nuovo Cimento; 22 C/3-4, 605613.

Neves L., Barbosa S., Pereira A. and Aumento F. (2010) - Soil gas concentration monitoring in an active granite quarry from Central Portugal. Geophysical Abstracts; Vol. 12, EGU2010-8006, 2010 EGU General Assembly 2010.

Papastefanou C., Manolopoulou M., Stoulos S., Ioannidou A. and Gerasopoulos E. (1999) - Radon measurements in association with earthquakes. Il Nuovo Cimento, 22 C/3-4, 393-397.

Pulinets S. A., Alekseev V. A., Boyarchuk B. A., Hegai V.V. and Depuev V. Kh. (1999) - Radon ionosphere monitoring as a means for strong earthquakes forecast. Il Nuovo Cimento; $22 \mathrm{C} / 3-$ 4, 621-626.

Tuccimei P., Mollo S., Vinciguerra S., Castelluccio M. and Solingo M. (2010) - Radon and thoron emissions from lithophysae-rich tuffs under increasing deformation: an experimental study. Geophys. Res. Lett.; 37, L05305.

Virk H. S. (1999) - Radon/helium studies for earthquakes prediction in N.-W. Himalaya. Il Nuovo Cimento; 22 C/3-4, 423-427

Zhang Wei (1999) - Research on relationships between escaping radon and stress-strain of the crust; Il Nuovo Cimento, 22 C/3-4, 437-442.

Zhang Zhaocheng and Zhang Wei (1999) - The correlation between variation of radon content in groundwater and earthquakes. Il Nuovo Cimento; 22 C/3-4, 443-447. 